Серія: Педагогічні науки. - Вип.3. - Бердянськ : БДПУ, 2019. - 453 с.

УДК 811.161.2:373.3

DOI 10.31494/2412-9208-2019-1-3-72-79

\title{
THE USE OF MULTIMEDIA IN THE SYSTEM OF METHODS AND TECHNIQUES OF TEACHER'S WORK IN THE SPEECH DEVELOPMENT OF PRIMARY SCHOOL PUPILS
}

\author{
ЗАСТОСУВАННЯ МУЛЬТИМЕДІЙНИХ ЗАСОБІВ \\ У СИСТЕМІ МЕТОДІВ І ПРИЙОМІВ РОБОТИ ВЧИТЕЛЯ \\ 3 РОЗВИТКУ МОВЛЕННЯ УЧНІВ ПОЧАТКОВИХ КЛАСІВ
}

\author{
Olena CHUPRINA, \\ Candidate of Pedagogical Sciences, \\ Senior Lecturer \\ Олена ЧУПРІНА, \\ кандидат педагогічних наук, \\ старший викладач \\ https://orcid.org/0000-0002-8935-976x \\ ch.m.helen28@gmail.com \\ Zhytomyr Ivan Franko State \\ Житомирський державний \\ University \\ 40 Velyka Berdychivska St., \\ Zhytomyr, 10008 \\ університет імені Івана Франка \\ $\triangle$ вул. Велика Бердичівська, 40 \\ Original manuscript received: October 01, 2019 \\ Revised manuscript accepted: December 11, 2019
}

\section{ABSTRACT}

The article explores the peculiarities of the use of multimedia in the system of methods and techniques of work on the speech development of primary school pupils. The content of the concepts of "method", "reception" is outlined, the attention is paid to the system of work on the speech development, aimed at enriching the vocabulary of pupils, the development of the grammatical structure of their speech; mastering the norms of the Ukrainian literary language; developing the ability to perceive, reproduce and construct oral and written utterances. The expediency of using multimedia means, which are intended to optimize the process of speech development of primary school pupils and which are relevant in the conditions of formation and development of the New Ukrainian school. school.

Key words: method, admission, multimedia, speech development, elementary

Постановка проблеми. Сучасні методи і прийоми навчання мови та розвитку мовлення ґрунтуются на традиціях вітчизняної школи. Проблему розвитку мовлення молодших школярів, зокрема добір методів, прийомів та вправ, представлено в працях В.Бадер, М. Вашуленка, Р. Вовкотруб, Т. Коршун, А. Ляшкевич, А. Нікітченко, М. Орап, О. Паскаль, С. Пенькової, О. Петрук та ін. У науковій літературі існує низка підходів до визначення понять "метод" і "прийом" навчання та їх класифікацій. У сучасній дидактиці "метод" розглядається як спосіб упорядкованої взаємозв'язаної діяльності вчителя й учнів, спрямований на розв'язання навчально-виховних завдань (А. Алексюк), а "прийом" навчання - елемент методу, часткове поняття щодо загального поняття "метод" (Коваль, 2008: 45). Якщо метод - це спосіб 
діяльності, то прийом є окремим кроком, дія в реалізації методу. На думку І. Лернера, метод - це дидактична модель діяльності педагога, яка реалізується в конкретних його діях - прийомах.

Існують усталені класифрікації методів навчання: за рівнем і характером пізнавальної активності учнів (І. Лернер, М. Скаткін), за джерелами знань (Є. Голант, Д. Лордкіпанідзе, С. Шаповаленко), за способом взаємодії вчителя й учнів на уроці (О. Біляєв, Є. Дмитровський, С. Чавдаров та ін.), за особистісно-діяльнісним підходом (Ю. Бабанський, В. Краєвський, А. Хуторський) тощо.

Метою статті $€$ аналіз методів і прийомів роботи вчителя з розвитку мовлення учнів початкових класів, окреслення особливостей застосування мультимедійних засобів на уроках української мови в початковій школі.

Виклад матеріалу. У методиці викладання української мови в школі проблеми добору та класифікації вправ і відповідних методичних прийомів, спрямованих на формування комунікативних умінь, представлені в працях О. Біляєва, Л. Варзацької, М. Вашуленка, С. Карамана, В. Мельничайка, М. Пентилюк, М. Стельмаховича, М. Успенського, О. Хорошковської, Г. Шелехової. С. Золотницька пропонує класифрікацію, побудовану на лінгвістичному принципі дихотомії - дослідниця виділяє вправи комунікативні та некомунікативні.

У методиці розвитку мовлення учнів початкової школи визначено такі методи, як інфрормаційно-рецептивні; імітаційні; репродуктивні; конструктивні; творчі; комунікативні.

Інформаційно-рецептивні методи навчання ґрунтуються на поєднанні інформаційного й рецептивного (або рецептивноперцептивного) методу учіння. До цієї групи методів належать: повідомлення нової навчальної інформації, пояснення нової навчальної інфрормації, постановка запитань (бесіда) та ін. Передача інфоормації відбувається за допомогою усного слова (повідомлення, пояснення), наочних посібників (таблиці, схеми), друкованого слова (підручника, посібника), а прийом інформації - за допомогою слухання, читання, спостереження, відтворення, заучування, відповідей на запитання.

Метод повідомлення готової інформації - основний метод ознайомлення учнів з лінгвістичним поняттям (Л. Федоренко). Прийоми цього методу: опорне повторення, предметні дії (виокремлення одиниць мови й мовлення), перефразування.

Метод пояснення готової інформації передбачає усну передачу інформації, пояснення лінгвістичного поняття, правил правопису, закономірностей мовних явищ.

Постановка інформаційних запитань або метод бесіди, полягає в проведенні певного виду бесіди (підготовча інформаційна, евристична, відтворювальна, узагальнююча, повторювальна) (Львов, 1985) шляхом формулювання інформаційних або проблемних запитань.

Імітаційні методи (методи навчання за зразками, спонукальнорепродуктивні методи) застосовують для формування навичок користуватися отриманою інформацією (К. Плиско). Учитель демонструє спосіб виконання 
дій, а учні їх відтворюють. У межах імітаційного методу застосовується метод мовного (мовленнєвого) розбору та репродуктивний. Імітаційний метод передбачає аналіз текстів-зразків, побудову власних висловлювань і текстів за аналогією, пошукову діяльність (вибір мовних одиниць), побудову моделей текстів-зразків, конструювання власних текстів за цими моделями, близькі до тексту усні та письмові перекази з творчим доповненням чи без них, інсценування, драматизацію, літературну творчість. До прийомів імітаційного методу належать: добір заголовків до частин тексту, усі види усних і письмових переказів, складання речень або компонентів тексту відповідно до якогось певного типу тексту, письмові твори за аналогією до прочитаних творів, переклади, відгуки про прочитані книги, ділові папери.

На думку М. Львова, репродуктивний метод ґрунтується на багаторазовому використанні засвоєних знань: "засобів мови, правил, алгоритмів тощо". До прийомів цього методу належать: репродуктивні повідомлення, репродуктивна бесіда, прийом репродуктивних вправ та ін.

Конструктивний метод полягає в організації навчальної практичної мовленнєвої діяльності учнів на основі здобутих теоретичних знань, спрямованої на побудову та перебудову текстів, речень тощо. До прийомів конструктивного методу належать логічні прийоми та вправи (побудова роздумів, доказів, виправлення логічних помилок і помилок у послідовності викладення думок тощо); прийоми та вправи, в основу яких покладено теорію тексту (складання текстів різних видів, редагування власних текстів тощо).

Творчий метод використовується для стимулювання творчої діяльності учнів і передбачає формування умінь учня набувати знання самостійно, досліджувати предмет або явище, робити висновки, а набуті знання застосовувати в практичній діяльності. Він включає школярів у процес самостійного творчого пізнання, сприяє формуванню навичок творчої діяльності, створює умови для формування пізнавальних інтересів, потребу в такому виді діяльності; забезпечує не тільки формування знань про текст, розвиток умінь і навиків мовної діяльності, але й сприяє розвитку творчих здібностей молодших школярів в єдності з вдосконаленням їх мовної здібності. Особливу увагу слід звернути на самостійне створення учнями тексту (твору).

Комунікативний метод спрямований на формування комунікативної компетентності; "комплекс методичних прийомів, які спираються на мовлення, на живе спілкування, на мовну комунікацію" (Вашуленко, 2011). В основу цього методу покладений мотив - бажання висловити думку, переконати, спонукати до дії, запитати про щось тощо. За характером мовленнєвої діяльності комунікативний метод аналогічний продуктивнотворчому, оскільки базується на розвитку й творчому застосуванні набутих мовленнєвих навичок, передбачає формування діалогічного й монологічного мовлення. Цей метод включає такі прийоми: створення мовленнєвих ситуацій, рольових ігор, казкових сюжетів, реклами, словесного малювання.

У роботі з розвитку мовлення учнів початкових класів особливу увагу варто приділяти прийомам та вправам, які виконують підготовчу фрункцію (словникова робота; робота зі словосполученням, реченням). 
У методиці навчання під терміном "вправа" розуміють спеціально організовану й цілеспрямовану діяльність, процес набуття, формування, удосконалення, розвитку, усвідомлення і закріплення знань, умінь і навичок (Ю. Пассов, О. Савченко, В. Сухомлинський та ін.).

Функційний принцип побудови системи вправ представлено в класифрікації $€$. Пассова (мовні, вправи-переклади, трансформаційні, підстановчі, мовленнєві, питально-відповідні, умовно-мовленнєві, імітаційні, власне репродуктивні) (Пассов, 2006: 114). За І. Салістром, виділяють два типи вправ: ті, які готують до мовлення, та власне мовленнєві, що підтверджується принципом мовленнєвого спрямування. Доцільність поділу вправ за способом формування умінь і навичок на імітаційні, оперативні та комунікативні довів у своїй праці М.Успенський (Коваль, 2008).

Розвиток зв'язного мовлення в початковій школі здійснюється за двома взаємопов'язаними напрямами - розвиток усного мовлення та формування писемного мовлення, які реалізуються в діалогах та монологах (Вашуленко, 2011).

Навчання учнів діалогічного мовлення здійснюється поетапно: від відтворення зразка до самостійної побудови діалогу. Із цією метою доцільно використовувати завдання на відтворення, розігрування діалогів з прочитаних казок, оповідань; на доповнення незавершеного діалогу; побудову діалогу за зразком; складання діалогу з опорою на допоміжні матеріали; побудову діалогу за ситуативним малюнком; створення діалогу за описаною ситуацією.

Вправами, що сприяють розвитку монологічного мовлення, визначено такі: робота над словом, словосполученням, реченням; конструювання тексту, його редагування, різні види переказів (докладний, стислий, вибірковий); твори (твір-опис, твір-розповідь, твір-міркування, твір за картино, за серією малюнків; твір на основі власного досвіду, твір на основі загадки та інше); складання ділових паперів (запрошення, оголошення, лист другові та інші) (Вашуленко, 2006).

Вагоме значення в роботі з розвитку мовлення учнів початкових класів відведено таким наочним методам, як: спостереження, екскурсії, екскурсії-огляди, розглядання предметних та сюжетних ілюстрацій, перегляд кінофрільмів, мультимедійних презентацій, телепередач, застосування дидактичних ігор тощо. Використання цих методів відповідає дидактичному принципу наочності, а також наочно-дієвому та наочно-образному характеру мислення учнів.

Однак формувати вміння працювати з такими ТЗН необхідно поступово, забезпечуючи успіх у роботі кожного школяра. Тому уроки української мови в комп'ютерному класі найдоцільніше організовувати за принципом групового навчання “учитель - учні". Роль учителя й учня почергово виконують діти. Спершу "учень" спостерігає за роботою "вчителя", ставить уточнювальні запитання. Пізніше учасники групи виконують програму спільно, обговорюють свої рішення. Утретє програму виконує "учень" самостійно, а "вчитель" спостерігає, дає поради. Колективне виконання програми виправдане лише тоді, коли вона складна в інформативному та навчальному планах. 
Значні можливості щодо активізації пізнавальної діяльності учнів на уроках мови із застосуванням колективних форм роботи мають інформативні (smart) дошки (назва походить від англ. - кмітливий, спритний, меткий). Робота з цим навчальним устаткуванням дає широкі можливості для організації пізнавальної діяльності школярів, забезпечує динамічність уроків. Необхідний лише дотик, щоб вибрати позначку, відкрити веб-сайт або пересунути зображення; учням достатньо торкнутися поверхні дошки палець працює, як мишка. Такий простий і швидкий доступ до інформації спонукає учнів до міркувань і створення нових ідей.

Уроки української мови 3 використанням комп'ютерних засобів навчання не тільки спонукають до активної роботи, а й допомагають донести матеріал до кожного учня в класі. Ніяке інше устаткування для навчального класу не дає таких можливостей. Великий екран, на який проєктується інформація, видно кожному, і вчитель має змогу заволодіти увагою всього класу. Учні бачать великі кольорові зображення і діаграми, взаємодіють 3 матеріалом, рухаючи літери, цифрри, слова і картинки. Дотиком пальця учень може працювати з різноманітними фігурами, шукати потрібну інформацію в мережі або робити презентацію. А за допомогою маркера, що знаходиться на спеціальній підставці, він пише на екрані електронним чорнилом. Зазначимо, що використання сучасних технологій у навчанні відповідає соціальним і психологічним особливостям учнів молодшого шкільного віку.

Мультимедійні засоби надають можливість урізноманітнювати методи та організаційні форми навчання. Для цього напряму досліджень характерне створення педагогічних технологій і методичних систем навчання, орієнтованих на формування вмінь провадити навчальну діяльність із використанням сучасних методів і засобів навчання, засобів інформаційної взаємодії й комунікації (Пінчук, 2006: 181].

В умовах становлення та розвитку Нової української школи залишаються актуальним застосування традиційних методів та прийомів розвитку мовлення учнів. Однак використання мультимедійних засобів в освітньому процесі оптимізує його перехід до якісно нового рівня, позитивно впливає на мотивацію школярів до навчальної діяльності, підвищує рівень їхньої спроможності й активності у виборі способів виконання завдань, що постають перед ними. Мультимедіа сприяють реалізації педагогічних цілей, інтегруючись в освітній процес і взаємодіючи з його компонентами - змістом, формами й методами навчання.

У навчальній програмі з української мови для початкової школи особливу увагу акцентовано на словниковій роботі. Лінгводидакти (О. Біляєв, М. Вашуленко, О. Лобчук, А. Люблінська, М. Осколова, В. Собко, Н. Тализіна, О. Хорошковська), які вивчали мовленнєвий розвиток особистості, розглядали збагачення словникового запасу учнів початкової школи як основу розвитку мовлення. На думку багатьох дослідників, із метою збагачення словникового запасу першокласників доцільно застосовувати різноманітні засоби навчання, серед яких важливе місце посідають як традиційні технічні засоби (аудіо-, відеозаписи), так й інноваційні (комп'ютер, SMART-дошка, анімація, презентація). 
У процесі збагачення словникового запасу учнів новими словами педагог застосовує традиційні в методиці прийоми: показ натуральних предметів або предметних малюнків із зображенням певного процесу, дії, якості предмета - його кольору, форми; елементарне логічне визначення предмета шляхом вказівки на видову або родову назву та його істотну ознаку; добір до слова одного або кількох синонімів; добір до слова протилежних за значенням; добір родової або видових назв; введення нового слова в речення; вказівка на слово, від якого походить те, яке пояснюється, або добір спорідненого; переклад; застосування ілюстрації в підручнику.

Ефективність впливу мультимедіа на збагачення словникового запасу багато в чому залежить від ступеня і рівня ілюстративності усного матеріалу. Візуальна насиченість навчального матеріалу робить його яскравим, переконливим і сприяє інтенсифікації процесу його засвоєння. “Комп'ютерна презентація дозволяє акцентувати увагу школяра на важливій інформації і створювати наочні ефектні образи у вигляді графічних композицій, схем" (Петренко, 1994: 17). Системне застосування засобів мультимедіа можливе впродовж вивчення навчальної теми, коли на кожному 3 уроків використовуються лише окремі їхні елементи (сукупність елементів).

Основними напрямами застосування мультимедіа як засобу збагачення словникового запасу першокласників $€$ демонстрація наочних матеріалів: різноманітних схем, малюнків; демонстрація процесів та явищ; презентація завдань, спрямованих на перевірку розуміння тих чи інших слів учнями. Мультимедійні засоби навчання значно поліпшують доступ до інформації, підвищують ефективність і мотивацію навчання, забезпечують нові шляхи подання інформації, які полегшують її розуміння, дають змогу для випробування власних ідей та проєктів, роблять учнів більш упевненими та здатними вирішувати проблеми самотужки. Водночас однією 3 найголовніших переваг застосування мультимедіа під час навчання $€$ можливість задовольнити індивідуальні потреби учнів.

Для збагачення словникового запасу дослідниками розроблено систему завдань, що охоплює словниково-логічні вправи, які допомагають не лише збільшити словниковий запас першокласника, а й логічно і правильно використовувати ці слова в повсякденному мовленні. Вони сприяють розвитку мислення, збагаченню й систематизації словникового запасу учнів. Нашу увагу привернули зразки словниковологічних вправ: називання предметів за вказаною ознакою; групування слів-назв предметів за певною ознакою; називання предметів за властивими їм діями; називання предметів за властивими їм ознаками; розподіл слів-назв предметів на дві чи три групи; добір до назв однорідних предметів слова, яке означає родове поняття; добір слів, що означають вид поняття, до узагальнюючих; вилучення зайвого слова 3 певної родової групи; творення нового слова (пропедевтика творення частин мови); складання елементарних логічних визначень; робота над реченням; робота над текстом (Паршина, 2008: 38).

Виконуючи запропоновані завдання, учні навчаються класифікувати (групувати) слова, порівнювати предмети і явища, 
встановлювати на основі цього схожість і різницю між ними. Логічні вправи допомагають дітям правильно співвідносити родові та видові поняття, визначати зв'язок між предметом і словом, яке позначає його.

Реалізацію більшості методів навчання, контролю та активізації пізнавальної діяльності учнів мультимедійні засоби забезпечують на якісно новому рівні. Практичне застосування засобів мультимедіа сприяє вдосконаленню або навіть частковій заміні в освітньому процесі таких класичних методів навчання, як методи усного викладу навчального матеріалу (розповідь, пояснення тощо), методи наочного і практичного навчання; методи закріплення отриманих знань, методи самостійної роботи, методи контролю та перевірки знань (Коваль, 2008).

Л. Паршина наголошує: мультимедійні засоби мають великий креативний потенціал, що постійно розвивається, дає змогу знаходити різноманітні цінні та дієві форми й методи самореалізації, сприяє реалізації принципів навчання. Мультимедійні засоби навчання мають потужний емоційний заряд, спонукають до пізнавальної діяльності, завдяки одночасному впливу на учня графічної, аудіовізуальної й візуальної інформації, доступності інформації за допомогою гіперпосилань (Паршина, 2008).

Висновок. Мультимедійні засоби суттєво впливають на емоційну сферу учня, сприяючи підвищенню пізнавальної активності, інтересу до предмета та навчання взагалі, активізації навчальної діяльності учнів. За допомогою інформаційних технологій вчитель може організувати вивчення нового навчального матеріалу, роботу над текстом, виконання вправ, формування стійких мовно-мовленнєвих умінь і навичок, збагачення словникового запасу, оволодіння нормами літературної мови тощо.

Застосування традиційних та інноваційних методів і засобів, поєднані з різними компонентами педагогічної майстерності учителя, формують, належне підґрунтя для оволодіння учнями навчального матеріалу, формування умінь правильно будувати зв'язні висловлення.

\section{Література}

1.Бєляєв О., Мельничайко В., Пентилюк М. та ін. Методика вивчення української мови в школі / О. Бєляєв, В. Мельничайко, М. Пентилюк та ін. - Київ : Радянська школа, 1987. - 246 с.

2.Вашуленко М. Українська мова і мовлення в початковій школі : метод. посіб. / М. Вашуленко. - Київ : Освіта, 2006. - 268 с.

3. Вашуленко М. Методика навчання української мови в початковій школі: навч.метод. посібн. / за наук. ред. М. Вашуленка. - Київ : Літера ЛТД, 2011. - 364 с.

4.Коваль Г., Деркач Н., Наумчук М. Методика викладання української мови : навч. посібн. / Г. Коваль, Н.Деркач, М. Наумчук. - Тернопіль: Астон, 2008. - 287 с.

5.Львов М. Методика развития речи младших школьников : пос. Для учителя. 2-е изд., перераб. / М. Львов. - Москва : Просвещение, 1985. - 176 с.

6.Паршина Л. Педагогические условия формирования компетенций студентов педвуза в процессе освоения мультимедиа : дисс. ... на соискание уч. степени канд. пед. наук : спец. 13.00.01./ Л. Паршина. - Саранск, 2008. - 222 с.

7.Пассов Е. Сорок лет спустя или сто и одна методическая идея. / Е. Пассов. - Москва: Глосса-пресс, 2006. - 240 с. 
8.Петренко А. Мультимедиа / под. ред. А. Петренко К.: Торговоиздательское бюро ВНV. - 1994. - 272 с.

9.Пінчук О. Дидактичний аспект проблеми визначення мультимедіа в освіті. Наукові записки. Серія педагогічні та історичні науки / О.Пінчук. - К.: Вид-во НПУ імені М. П. Драгоманова, 2006. - Bun. LXIV (64). - С. 178-184.

\section{References}

1.Byelyayev O., Mel’ny`chajko V., Penty’lyuk M. (1987). Metody`ka vy`vchennya ukrayins`koyi movy` v shkoli [Methods of studying Ukrainian at school], Kyiv : Radyans`ka shkola [in Ukrainian].

2. Vashulenko M. (2006) Ukrayins`ka mova i movlennya v pochatkovij shkoli : metod. posib. [Ukrainian language and speech in elementary school], Kyiv : Osvita [in Ukrainian].

3.Vashulenko M. (2011) Metody`ka navchannya ukrayins`koyi movy` v pochatkovij shkoli: navch.-metod. posibn.[ Methods of teaching Ukrainian in elementary school], Kyiv : Litera LTD [in Ukrainian].

4.Koval G., Derkach N., Naumchuk M. (2008) Metody`ka vy`kladannya ukrayins 'koyi movy' : navch. posibn [Methods of teaching Ukrainian], Ternopil’: Aston, 287 s. [in Ukrainian].

5. L’vov M. (1985) Metody`ka razvy`ty`ya rechy` mladshy`x shkol’ny`kov : pos. Dlya uchy telya. 2-e y`zd., pererab. [Methods of development of speech of primary school students], Moskva : Prosveshheny`e [in Russian].

6. Parshy`na L. (2008) Pedagogy`chesky`e uslovy`ya formy rovany ya kompetency`j studentov pedvuza v processe osvoeny`ya mul'ty’medy`a : dy`ss. ... na soy`skany`e uch. stepeny` kand. ped. nauk : specz. 13.00.01 [Pedagogical conditions for the formation of competencies of pedagogical students in the process of mastering multimedia] Saransk [in Russian].

7. Passov E. (2006) Sorok let spustya y`l` sto y` odna metody`cheskaya y'deya [Forty years later or a hundred and one methodological idea], Moskva: Glossapress [in Russian].

8.Petrenko A. (1994) Mul'ty`medy`a [Multimedia], Kyiv : Torgovoy`zdatel`skoe byuro BHV [in Ukrainian].

9. Pinchuk O. (2006) Dy`dakty`chny`j aspekt problemy` vy`znachennya mul'ty`media $v$ osviti. Naukovi zapy`sky`. Seriya pedagogichni ta istory`chni nauky [Didactic aspect of the problem of defining multimedia in education], Kyiv : Vy`d-vo NPU imeni M. P. Dragomanova, (64), 178-184 [in Ukrainian].

\section{АНОТАЦІЯ}

У статті досліджено особливості застосування мультимедійних засобів у роботі з розвитку мовлення учнів початкових класів. Окреслено зміст понять "метод", “прийом", акцентовано увагу на системі роботи з розвитку мовлення, спрямованої на збагачення словникового запасу учнів, розвиток граматичної будови їхнього мовлення; засвоєння норм української літературної мови; формування умінь і навичок сприймати, відтворювати та будувати усні й писемні висловлювання. Обгрунтовано доцільність використання мультимедійних засобів, що покликані оптимізувати процес розвитку мовлення учнів початкових класів та є актуальними в умовах становлення та розвитку Нової української школи.

Ключові слова: метод, прийом, мультимедійний засіб, розвиток мовлення, початкова школа. 